\title{
The Analysis of Critical Thinking Skill of Version P21 in Solving the Problems of Two Dimensional Arithmetic Derived from the Implementation of Guided Discovery Learning
}

\author{
Afif Alfa Robi ${ }^{1}$, Hobri ${ }^{2}$, Dafik ${ }^{2}$ \\ ${ }^{1}$ University of Jember, Master Program in Mathematics Education, \\ Jember, East Java, Indonesia \\ afifalfarobi@gmail.com \\ ${ }^{2}$ University of Jember, Departement of Mathematics Education, \\ Jember, East Java, Indonesia
}

\begin{abstract}
:
This study aims to analyze the critical thinking skills of P21 students in solving Arithmetic Two Dimensional problems through the application of Guided Discovery Learning. GDL is a learning process that occurs when students are not presented with material in final form but learners are expected to organize their own material with guidance from educators if needed. Implementation of GDL in learning process is expected to improve students' thinking ability, especially critical thinking ability version P21. According to P21, in the 21st century, every individual is required to have $4 \mathrm{C}$ 's skills in order to compete globally and one of 4C's skills is critical thinking. By having these skills, learners are expected to achieve success in life and work. The subjects of this study are discrete mathematics class students, as many as 64 students. Research steps are by providing initial knowledge of Two Dimensional Arithmetic materials through GDL method and Student Worksheet (LKM) then at the end of student learning work on Test Mastery of Teaching Materials (TPBA). The test results are then analyzed using the P21 critical thinking indicator that is reasoned effectively, using a system of thinking, making judgments and decisions. From the analysis result of Teaching Material Mastery Test obtained data about critical thinking level of students, in class A there are 25 students being in very high category (level 4), 10 students are in high category (level 3) and 9 students are in medium category (level 2). While in class $C$ there are 22 students being in very high category (level 4), 4 students are in high category (level 3) and 4 students are in medium category (level 2). The study also produced a two dimensional arithmetic monograph. From the results of this study can be concluded that the application of GDL has a positive effect in developing students' critical thinking skills in solving two-dimensional arithmetic problems.
\end{abstract}

Keywords: critical thinking P21, guided discovery learning, two dimensional arithmetic monograph.

\section{Introduction}

In the 21 st century, education faced different challenges than the previous era. This is due to the rapid development of science and technology and it is a feature of the era of globalization. Such circumstances make every individual easy to access and obtain information (As'ari, 2014). Globalization era and rapid technological developments resulted in several countries redesigning learning system in schools. Freedom of Internet access causes learners to get different types of information from a variety of sources. But this rapidly changing world has an impact on the difficulty of getting the right information about what competencies the learners should have in order to achieve success in the future. Educators are required to facilitate learners to develop their potentials. This is not an easy challenge and also a small responsibility to prepare young people in the face of demands in the 21 st century.

P21 (Partnership for 21st Century Learning) develops a 21 st Century learning framework that requires learners to have the skills, knowledge and skills in technology, media and information, learning and innovation skills and life and career skills (P21, 2015). This framework also describes the skills, knowledge and skills that must be mastered so that learners can achieve success in life and work. 
According to P21, learners should have "Four Cs" or it can also be written as 4C's skills, and they are crictical thinking, communication, collaboration and creativity in order to compete in the 21 st century. If learners do not have these skills so that learners can not meet the demands of the era of globalization or difficult to compete in the 21 st century. As a result, they have difficulty in achieving success in the future.

One of the $4 \mathrm{C}$ 's skills mentioned above is critical thinking. Critical Thinking is a skill to understand a complex problem, to connect information with other information, so that eventually there are various perspectives in finding solutions to a problem. Critical thinking is needed to verify the truth of the information, so that it can decide that information deserves to be rejected or accepted (As'ari, 2014). Critical thinking skills must be owned by every individual so as not to easily believe in an information that is not necessarily true and not in a hurry to take decisions in taking action (Hidayanti, 2016). Muhfahroyin (2009) states that to face the rapid changes of the world is to form a culture of critical thinking in society. The main priority of an educational system is to educate learners about how to learn and think critically.

Another reason for the need of the culture of critical thinking is that the world expresses their interest and concern for thinking skills because they get the facts about the inability of university graduates to make their own decisions independently. Since the welfare of a nation depends on its people, it is necessary and reasonable if the mind is the focus of educational development (Shukor, 2001). Some educational research findings also show that critical thinking is able to prepare learners to think in various disciplines, and can be used to fulfill the intellectual needs and the development of potential learners, because it can prepare learners to live careers and real life (Liliasari, 2001).

Critical thinking skills can be taught and developed in various ways, one of which is through a series of classroom activities. One of the sciences that can be used to develop critical thinking skills is mathematics. Mathematics has a complete and clear structure and study between the concepts. Critical thinking activities can be seen from the skills of learners in solving problems with accurately and systematically. In addition, one of the goals of learning mathematics is to train learners to have critical thinking skills.

One branch of mathematics is discrete mathematics and two-dimensional arithmetic is one of the materials on discrete mathematics. So twodimensional arithmetic can be used to practice critical thinking skills. Arimetics Two Dimensions in this research is two-dimensional arithmetic containing components of row $i$ and column $i$ with partition technique. The symbol $P_{m, d}^{n}(i, j)$ where $P$ is the partition, denotes many columns $n$ and many rows $m$ where $1 \leq i \leq n$ and $1 \leq j \leq m$ and $d$ represent the difference between two successive series of columns.

Table 1: Two dimensional arithmetic

\begin{tabular}{|c|c|c|c|c|c|c|c|}
\hline 11 & 1 & 2 & 3 & 4 & 5 & \begin{tabular}{|l|}
$\ldots$ \\
\end{tabular} & $n$ \\
\hline 1 & $P_{1, d}^{1}$ & $P_{1, d}^{2}$ & $P_{1, a}^{3}$ & $P_{1, A}^{4}$ & $P_{1, d}^{5}$ & $\cdots$ & $P_{1, A}^{n}$ \\
\hline 2 & $P_{2, d}^{1}$ & $P_{2, d}^{2}$ & $P_{2, a}^{3}$ & $P_{2, \lambda}^{4}$ & $P_{2, d}^{5}$ & $\ldots$ & $P_{2, A}^{n}$ \\
\hline 3 & $P_{3, d}^{1}$ & $P_{3, d}^{2}$ & $P_{3, d}^{3}$ & $P_{3, d}^{4}$ & $P_{3, d}^{5}$ & $\cdots$ & $P_{3, d}^{n}$ \\
\hline i & : & $\ddagger$ & ! & $\vdots$ & $\vdots$ & $:$ & : \\
\hline$m$ & $P_{m, d}^{1}$ & $P_{m, d}^{2}$ & $P_{m, d}^{3}$ & $P_{m, l}^{4}$ & $p_{m, A}^{s}$ & $\ldots$ & $P_{m, 4}^{n}$ \\
\hline Sum of & $\sum_{j=1}^{m} P_{i, d}^{1}$ & $\sum_{j=1}^{m} P_{j, d}^{z}$ & $\sum_{j=1}^{m} P_{j, d}^{3}$ & $\sum_{j=1}^{m} P_{j, d}^{4}$ & $\sum_{j=1}^{m} P_{f, d}^{5}$ & .. & $\sum_{j=1}^{m} P_{i, d}^{n}$ \\
\hline
\end{tabular}

In this research, two-dimensional arithmetic tables have special characteristics, that is the difference between two successive rows of columns is always fixed (d). In this study, it is developed some two dimensional arithmetic pattern and general formula. The following is an example of a two dimensional arithmetic table with $d=\frac{m}{2}, n \geq 3$, and $m$ even.

Table 2: Example of a two dimensional arithmetic

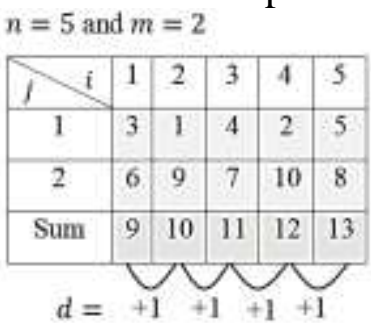

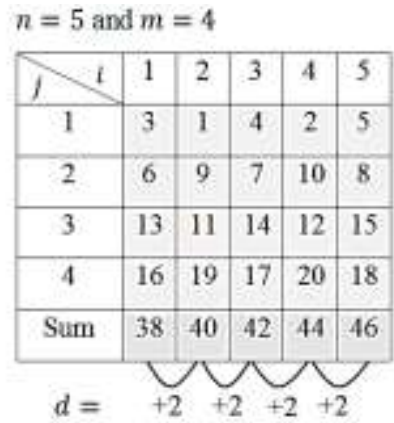

One of the learning models that can train critical thinking skills is the Guided Discovery Learning. According to Castronova (2002), discovery learning is part of constructivist learning. Discovery learning includes a learning model and strategies that focus on active learning opportunities for learners. Abel and Smith (1994) revealed that the educator acts as a facilitator guiding learners through questions that lead learners to connect the knowledge they already have with the knowledge being studied. Learners are 
encouraged to think for themselves, analyze themselves, so they can find concepts, principles, or procedures based on teaching materials provided by educators. In addition, Borthick and Jones (2000) suggest that discovery models encourage learners to learn to recognize a problem, characterize the solution, find relevant information, build strategies to find solutions, and execute the chosen strategy. According to Bruner (in Kemendikbud, 2013) discovery learning can be defined as the learning that takes place when the student is not presented with subject matter in the final form, but rather is required to organize it him self.

According to Brosnahan (2001), guided discovery learning is a teaching method in which teachers guide learners through open ended activities in order to encourage learners to discover for themselves the concepts being studied. One of the most important things in guided discovery learning is that teachers should try to lead learners to understand concepts by asking questions and suggesting ways to see a problem. Teachers are instructed to avoid conveying ideas to learners directly. Teachers provide questions that enable learners to find themselves a particular concept. If the teacher has tried to direct the learners but the learners still can not find the concept itself then the teacher can convey the concept directly on condition if it is really needed.

Kemendikbud in Robi (2016) describes the learning syntax of guided discovery learning such as stimulation, problem statement, data collection, data processing, verification, generalization. Stimulation at this stage serves to provide a learning interaction condition that can develop and assist students in exploring materials. Stages The problem statement gives learners the opportunity to identify and analyze the problems they face. Problem statement is a useful technique in building students so they get used to finding a problem. Data collection stages function to answer questions or to prove whether or not the hypothesis is true. Learners are given the opportunity to gather relevant information, read literature, observe objects, interview with resource persons, conduct their own tests and so on. The consequence of this stage is that learners actively learn to find something related to the problems encountered by connecting the problem with the knowledge already possessed. Data processing is also called categorization that serves as the formation of concepts and generalizations. From these generalizations learners will gain new knowledge about alternative solutions that need to get a logical proof. Verification aims to make the learning process work well and be creative if the educator provides an opportunity for the learner to discover a concept, theory, rule or understanding through the examples he or she encounters in his life. The generalization stage is the process of drawing a conclusion that can serve as a general principle and applies to all the same events or problems, taking into account the verification results.

Some of the advantages of the guided discovery learning model are as follows: (1) learners can actively participate in the learning presented, (2) grow and instill inquiri attitude (3) support the problem solving ability of learners, (4) the material being studied can attain a high level of ability and last longer because the learners are involved in the process of finding it (Rochaminah, 2008).

\section{Research Method}

This research includes descriptive research with qualitative approach, because this research will describe and analyze students' critical thinking skill in solving two dimensional arithmetic problem through GDL application.

This research was conducted in Mathematics Education program, Faculty of Teacher Training and Education (FKIP), University of Jember. The population in this study is all 4th semester students who take discrete mathematics course. The number of students is 74 people with the details of A-class students as many as 44 people and class C of 30 people.

The steps in this study can be divided into the following flowcharts:

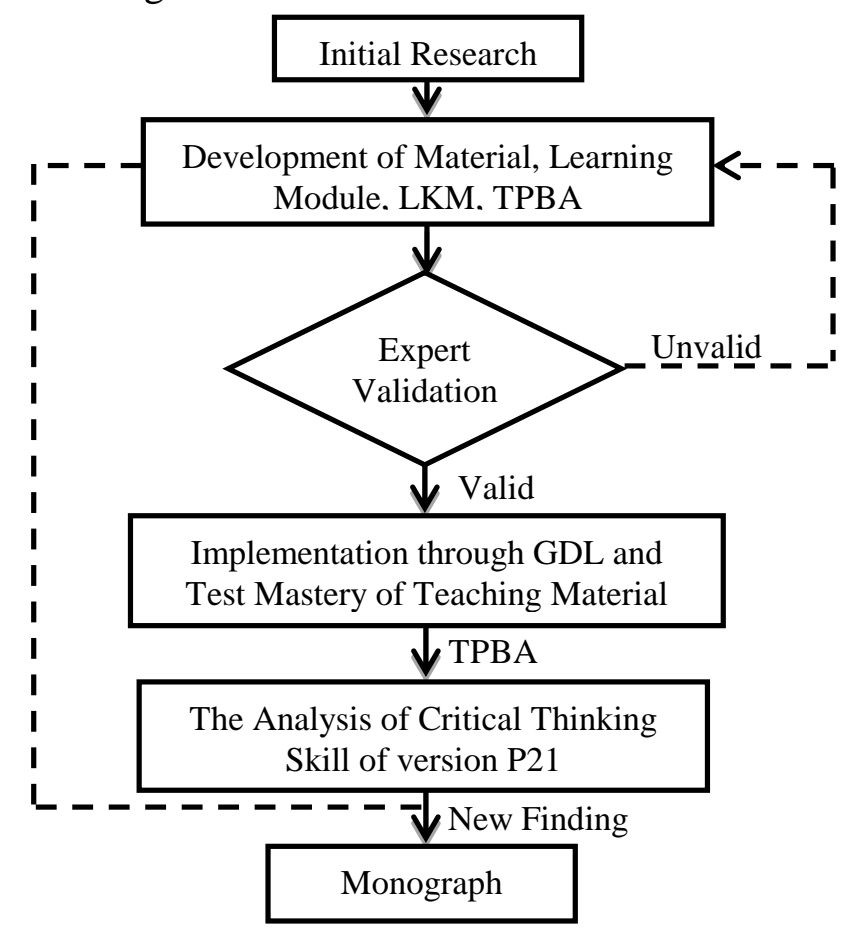

Figure 1: Flowcharts of research 
Instrument in this research is critical thinking ability test which in this research referred as test master of teaching material (TPBA) and assessment rubric. The test of mastery of the teaching materials consists of three questions on the pattern material and the general formula of two-dimensional arithmetic.

The first question is designed to measure indicators of "reasoning effectively", the second question for measuring "using system thinking" indicators, and the third question for measuring indicators "making judgments and decisions." In this study the measured data were the data of students' critical thinking skill test scores Teaching Material Mastery (TPBA) activity is student's skill in determining pattern and construct general formula of Two Dimensional Arithmetic.

The data of students' work on the test were each scored in accordance with the guidelines or rubric of critical thinking skill assessment that have been prepared by the researcher. Furthermore, the TPBA result data is captured and analyzed by determining the percentage of achievement of each aspect of the indicator. Percentage of compliance of each aspect of indicator of critical thinking ability based on formula:

$$
P_{\mathrm{i}}=\frac{I_{\mathrm{i}}}{n} \times 100 \%
$$

Information:

$P_{i}$ is the percentage of compliance with the $i$-th indicator

$I_{\hat{i}}$ is a lot of students who meet the indicator of critical thinking skills to- $i$

$n$ is the number of students taking the test

Adapted from Hidayanti (2016: 279)

In addition to the percentage calculation for each aspect of critical thinking skills, the researcher also determines the percentage score criteria obtained by the students by using the following formula:

$$
K_{\mathrm{i}}=\frac{m_{\mathrm{i}}}{n} \times 100 \%
$$

Information:

$K_{\mathrm{i}}$ is the percentage of critical thinking skills of the -i student

$m_{\mathrm{i}}$ is the total score of the-i critical students' critical thinking skill

$n$ is the number of students taking the test

Adapted from Amasari (2011: 36)

Furthermore, the calculation result of the percentage score of each student is interpreted by using the criteria table of critical thinking skill based on the percentage of the following test scores:
Table 3: Criteria of critical thinking

\begin{tabular}{|c|l|l|l|}
\hline & $\begin{array}{l}\text { Percentage } \\
\text { Score }\end{array}$ & Criteria & Level \\
\hline 1 & $89 \%<K_{\mathrm{i}} \leq 100 \%$ & $\begin{array}{l}\text { Very } \\
\text { high }\end{array}$ & $\begin{array}{l}\text { Level } \\
4\end{array}$ \\
\hline 2 & $79 \%<K_{\mathrm{i}} \leq 89 \%$ & High & $\begin{array}{l}\text { Level } \\
3\end{array}$ \\
\hline 3 & $64 \%<K_{\mathrm{i}} \leq 79 \%$ & Medium & $\begin{array}{l}\text { Level } \\
2\end{array}$ \\
\hline 4 & $54 \%<K_{\mathrm{i}} \leq 64 \%$ & Low & $\begin{array}{l}\text { Level } \\
1\end{array}$ \\
\hline 5 & $K_{\mathrm{i}} \leq 54 \%$ & Very low & $\begin{array}{l}\text { Level } \\
0\end{array}$ \\
\hline
\end{tabular}

$K_{\mathrm{i}}$ is the test score percentage

Adapted from Amasari (2011: 35) dan Kurniasih (2010a: 91)

\section{Result and Discussion}

Initial activity of this research is to do research planning which includes observation and analysis of student behavior, curriculum and syllabus study about two-dimensional arithmetic material, investigation of supporting resources used by lecturer in learning activities and learning tools what is needed and research indicator to analyze students' critical thinking skills from the results of the teaching material mastering test.

After doing the planning, the researcher develops the instructional tools needed in the research and test of mastery of teaching materials (TPBA). Furthermore the learning device is validated by experts. Learning device validation results include Learning Module, Student Worksheet (LKM) and Test Mastery of Teaching Material (TPBA) are presented in the following diagram.

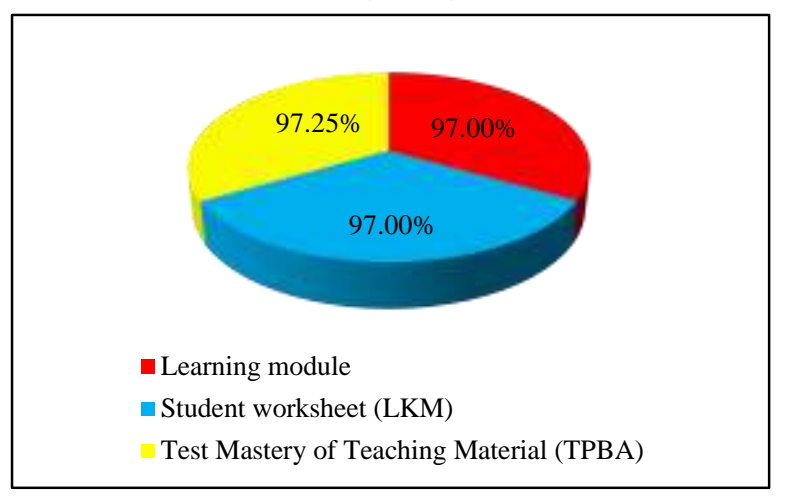

Figure 2: Diagram of learning device validation

Validation results from three validators indicate that learning tools are appropriate to be used in learning or research activities in the classroom. The validator also provides notes, comments and suggestions for improvements to the learning tool to be used in the study. Here are some views of the 
Student Worksheet (LKM), Test Mastery of Teaching Material (TPBA) and Monograph:
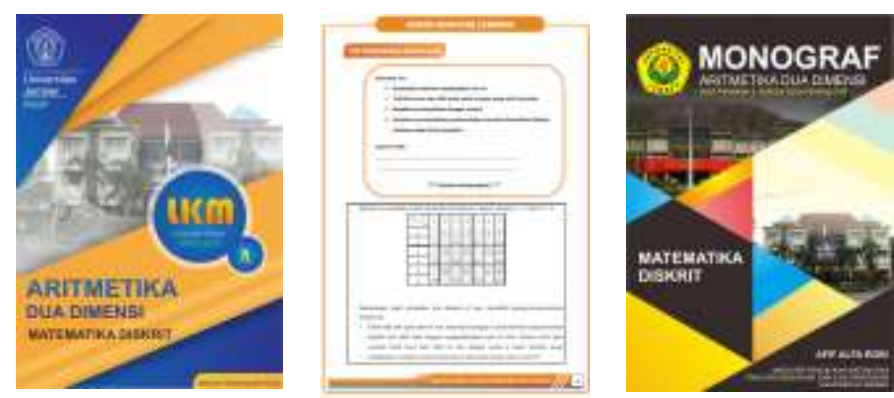

Figure 3: View of learning device

The study was conducted four times. The first and second meetings discussed about the general twodimensional arithmetic patterns and formulas. The third meeting discussed the application of twodimensional arithmetic in the graph. The fourth meeting examined the combined two-dimensional arithmetic partitions and graph labeling. In general, learning activities consist of preliminary activities, core and cover.

At the beginning of the lesson, the lecturer conveys the learning objectives and explains a little information about the steps in the guided discovery learning model: stimulation, problem statement, data collection, data processing, verification, generalization. Lecturers provide motivation to students by giving them information about the results of previous research and opportunities to conduct research on this material in order to serve as the final project. Lecturers divide the students into groups, with each group consisting of 2 to 3 people. After all the students formed a group, the lecturers distributed the LKM to each group. After all groups get the LKM, the lecturer gives a brief description of the material discussed in the LKM.

Furthermore, students discuss and try to understand the material in the LKM. If there are groups that have difficulty then the lecturer acts as a facilitator by providing a little guidance so that they can find their own concepts learned. In the LKM has provided guidance or guidance in finding their own concepts on the mteri being studied. Critical thinking skills are needed in the process of solving problems in the LKM. For example when students analyze patterns and construct the general formula of twodimensional arithmetic. Students are also required to evaluate or investigate the correctness of established formulas. After the completion of the LKM work, the lecturer appoints the group who has finished working on the LKM to present the results of the discussion in front of the class. During the presentation process, other groups are allowed to ask if they have difficulty understanding the group's explanation, or to provide a rebuttal or may also answer differently from the group presenting. Lecturers become facilitators by helping groups who are experiencing difficulties and guiding them in drawing conclusions at the end of the lesson.

During the implementation of learning, the activities of researchers who act as lecturers in managing the class and the activity of students in the class is assessed by the observer. It aims to determine whether the learning process is running well. Indicators of lecturer activity assessed by the observer at the initial activity include (1) motivating students, (2) presenting or giving problems, and (3) delivering the learning steps. Indicators in core activities include (1) organizing students in heterogeneous learning groups, (2) directing and guiding students to find concepts, (4) encouraging students to be actively involved in learning activities, (5) guiding students and groups to work on LKMs, (6) motivating the group to present the results of the group discussion in front of the class, (6) encourage students to compare and discuss the answers in class discussions. While the indicators on closing activities, among others, provide reinforcement and guide students to draw up conclusions Here is the percentage of the average score of observation results of activities of researchers who act as a lecturer in the learning process.

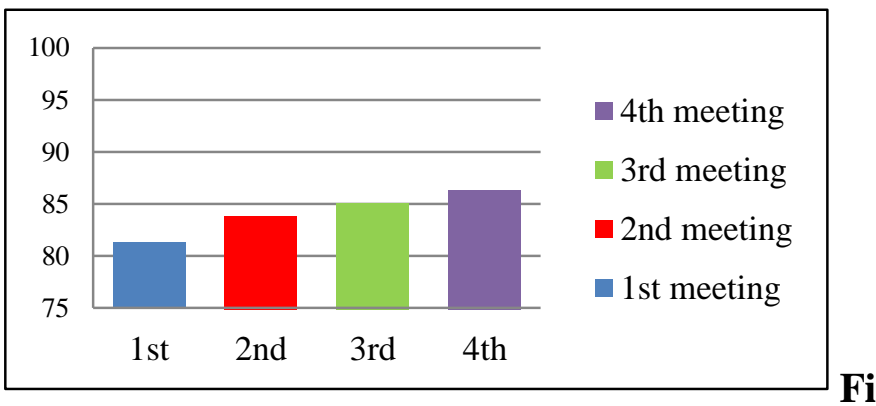

gure 4: Percentage diagram of lecturer activity

Based on the data in the diagram above, the average percentage of observation result score of lecturer activity in the learning process always increased from the first meeting to the fourth meeting.

In general, student activities in learning activities consist of initial activities, core and closing. Student activeness indicators assessed by the observer in the initial activities include students have attention and a sense of motivation towards the presentation of indicators and materials. Indicators in the core activities include (1) students discussing among group members in solving problems (understanding problems, explaining problems and solving problems), (2) students can present group discussion 
results in front of the class well, and (3) students can compare and discuss answers with other groups.

While the indicators on closing activities, among others, students can make conclusions from the learning activities. Here is the average percentage score of observation results of student activities in the learning process.

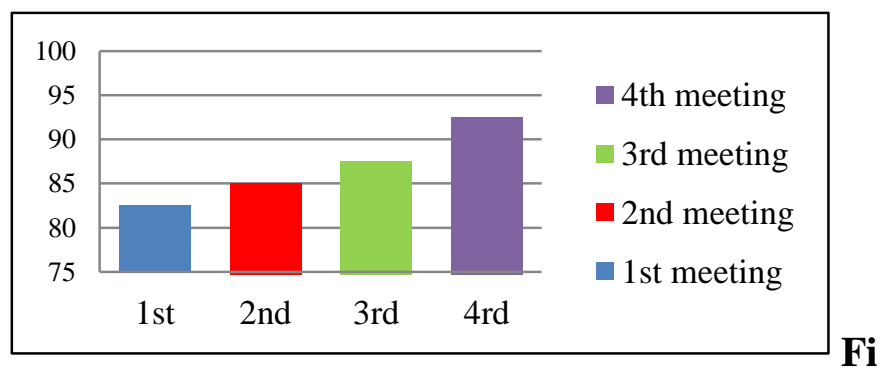

gure 5: Percentage diagram of student activity

Based on the data in the diagram above, the average percentage score of student activity observation result in the learning process also increased from the first meeting until the fourth meeting.

The final activity in this research is to analyze students' critical thinking skill based on the result of master learning result test. Here are examples of test results that represent critical thinking skills at level 4 or very high criteria.

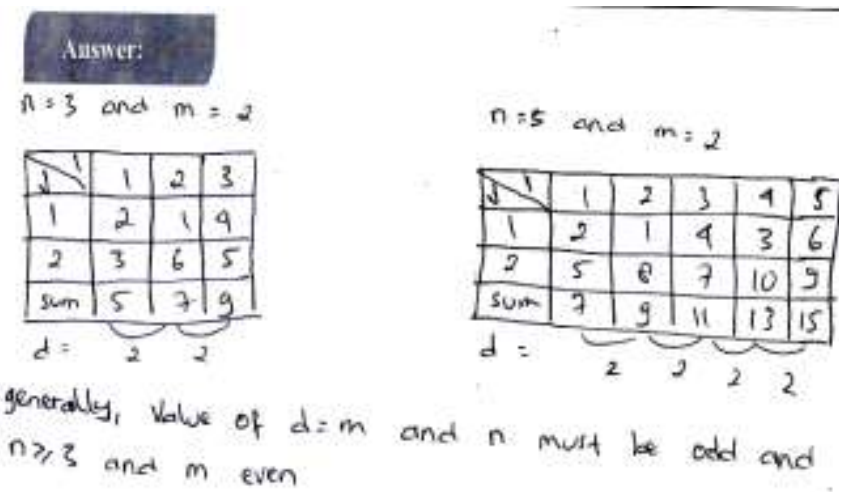

Figure 6: Reasoning effectively

The answer of question 1 above has met the indicator reasoning effectively that is able to generalize the values $d, m$ and $n$ correctly.

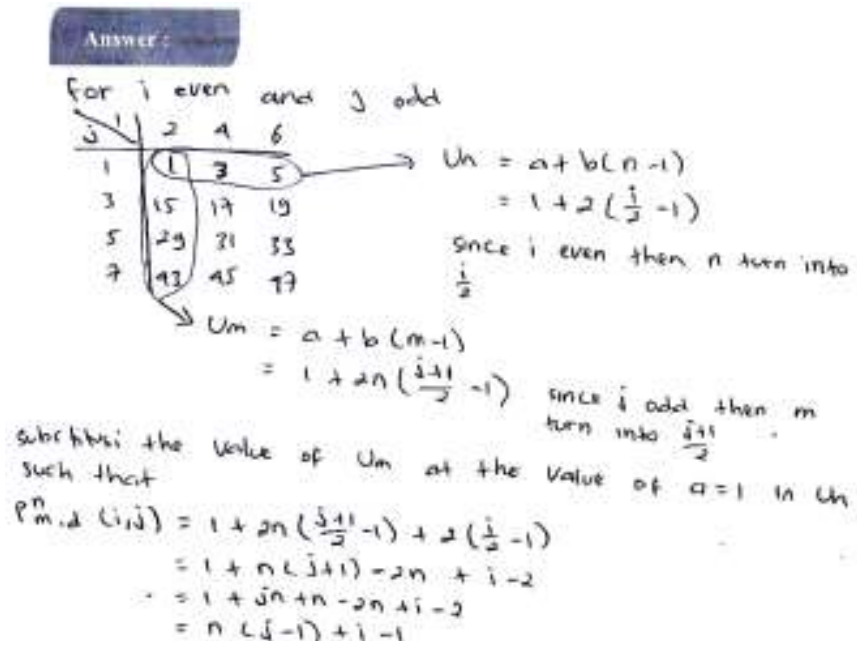

Figure 7: Using system thinking

Part of the answer to the question 2 above meets the indicator using system thinking that is capable of analyzing patterns by categorizing the values of $i$ and $j$ correctly and generalizing $U_{m}$ and $U_{n}$ values correctly and connecting the general form $U_{m}$ and $U_{n}$ to produce the form $P_{m_{d}}^{n_{d}}\left(i_{i}, j\right)$ with particular $i$ and $j$ correctly.

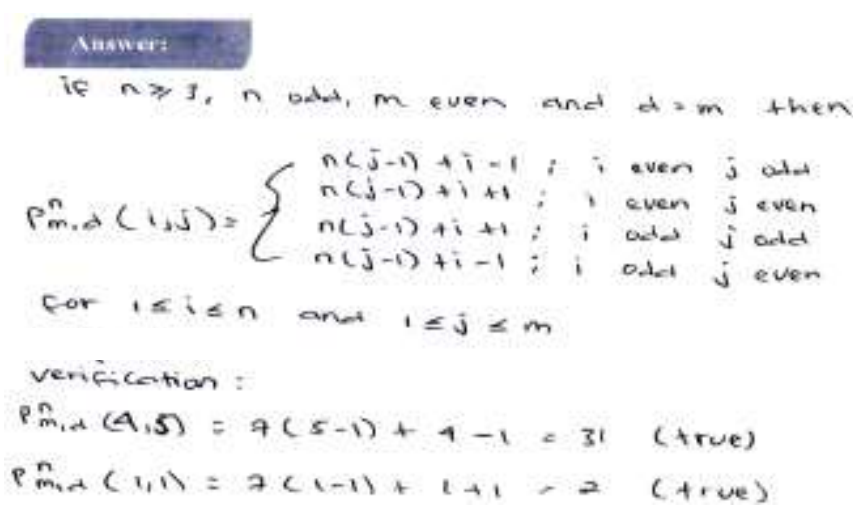

Figure 8: Making judgments and decisions

The answer of question 3 above has fulfilled the indicator of making judgments and decisions that is capable of writing the general formula $P_{m_{j}}^{\mathrm{m}}\left(i_{j} j\right)$ correctly and completely and verifying the correctness of the formula appropriately.

Researchers have conducted tests on the subject of this study that is in class A of 44 students and class $\mathrm{C}$ as many as 30 students. The critical level of critical thinking used is: level 0 (very low), level 1 (low), level 2 (medium), and level 3 (high) and level 4 (very high). After the results of the Test Mastery of Teaching Material (TPBA) were analyzed, the researchers got the result that the critical thinking level of the students was at three levels from the five available levels. Levels of critical thinking include level 2, level 3, and level 4. Consecutively, in class $\mathrm{A}$ and class $\mathrm{C}$ there are 25 and 22 students who are at level 4 then 10 and 4 students are at level 3, and 9 and 4 students are at level 2.

The following will present a comparison chart of critical thinking skills on each critical thinking level of class A and class $\mathrm{C}$.

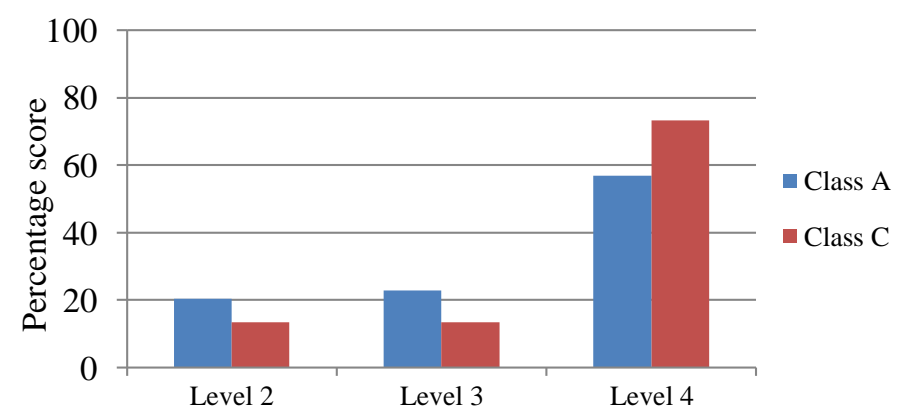

Figure 9: Comparison chart of critical thinking level 
Here is a comparison of critical thinking skills of each class $\mathrm{A}$ and class $\mathrm{C}$ indicator.

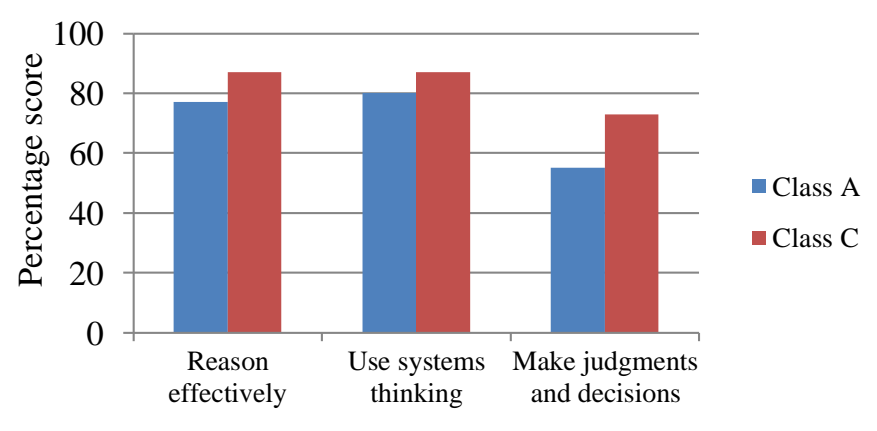

Figure 10: Comparison chart of critical thinking skills

\section{Conclusion and Suggestion}

Based on the results of research. It can be concluded that the critical thinking skills of students in solving the problems of two-dimensional arithmetic derived from the implementation of guided discovery learning is very diverse. From the analysis result of Teaching Material Mastery Test, it was obtained a data about critical thinking level of students, in class A there are 25 students being in very high category (level 4), 10 students are in high category (level 3) and 9 students are in medium category level 2). While in class $\mathrm{C}$ there are 22 students are in very high category (level 4), 4 students are in high category (level 3) and 4 students are in moderate category (level 2). Researchers give suggestions to researchers to produce better, these suggestions include: the development of twodimensional arithmetic materials can still be continued and novelty research should also be considered.

\section{References}

1. Amasari, F. H, "The Efforts to improve the critical thinking and creative thinking of students of class X administration office (AP) SMK Negeri 1 Depok in learning mathematics with problem posing method of presolution posing type". University of Yogyakarta, Yogyakarta, 2011.

2. As'ari, A.R, "Ideas for Developing Critical Thinking at Primary School Level". Internasional seminar Addressing Higher Order Thinking: Critical Thinking Issues in Primary Education. Held by Unversity of Muhammadiyah Makasar, April 12-13, 2014. [Online].

Avalaible: https://www.researchgate.net/publication/2736 34746_Ideas_for_Developing_Critical_Thinkin g_at_Primary_School_Level
3. Borthick, A.F., Jones, D.R, "The Motivation for Collaborative Discovery Learning Online and its Application in an Information Systems Assurance Course", Issues in Accounting Education, 15, (2), 181-210, 2000.

4. Brosnahan, H. L, Effectiveness of Direct Instruction and Guided Discovery Teaching Methods for Facilitating Young Children's Concepts, University of Carnegie Mellon, Pennsylvania, 2001.

5. Castronova, J, Discovery Learning for the $21^{\text {st }}$ Century : Article Manuscript. 2002. [Online]. Available:

http://citeseerx.ist.psu.edu/viewdoc/download? $\underline{\text { doi}=10.1 .1 .129 .4738 \& r e p=r e p 1 \& \text { type }=\text { pdf. }}$.

[Accessed: July 23, 2016]

6. Dafik, Hasan, M., Azizah, Y. N., Agustin, I. H, A Generalized Shackle of Any Graph $\mathrm{H}$ Admits a Super H-Antimagic Total Labeling, CGANT University of Jember, Jember, 2010.

7. Hidayanti, Dwi, The Analysis of Critical Thinking Skills of SMP Class IX Students In the Material of Cultivation, National Conference on Mathematics and Learning Research (KNPMP I) University of Muhammadiyah Surakarta, 2016.

8. Hobri, Model-Model Pembelajaran Inovatif (Bahan Bacaan Untuk Guru), Center For Society Studies (CSS), Jember, 2010.

9. Kemendikbud, Model Pembelajaran Penemuan (Discovery Learning), Kemendikbud, Jakarta, 2013.

10.Kurniasih, Ary Woro, Growth of Critical Thinking Skill of Student of Mathematics Education Study Program of FMIPA UNNES in Solving Mathematics Problem, Thesis: University of Malang, 2010a.

11.Liliasari, "IPA Learning Model to Improve High-Level Thinking Skills of Teacher Candidates as New Trends in Globalization Era", Journal of Teaching MIPA, Vol. 2 No. June 1st, 2001.

12.NEA, Preparing 21st Century Studenrs for a Global Society, 2017. [Online]. Available: https://www.nea.org/assets/docs/A-Guide-toFour-Cs. Page 8-9.

13.P21. The Intellectual and Policy Foundations of the 21st Century Skills Framework. Washington DC, Partnership for 21st Century Skills, 2015.

14. Robi, A.A, "Discovery Learning Mathematics based learning", Proceedings of the National Seminar on Mathematics Education entitled The Role of Mathematics and Learning in 
Developing Local Cultural Wisdom to Support

Nation Character Education, Faculty of Teacher Training and Education, University of Madura, Page 33-37, 2016.

15.Rochaminah, S, "The Use of Discovery Methods to Improve Mathematical Critical Thinking Skills of Teacher-education Students". 2008. [Online]. Available: https://www.scribd.com/doc/50713700/07-

Sutji-Rochaminah-Penggunaan-MetodePenemuan-untuk-meningkatkan-kemampuan. [Accessed: August 20, 2016]

\section{Author profile}

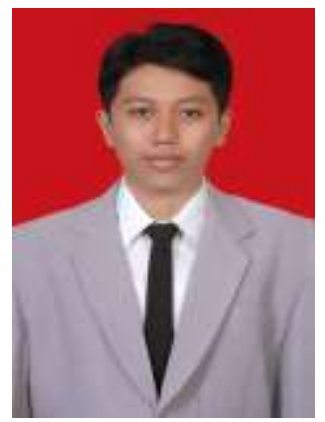

Afif Alfa Robi was born on July 29th, 1987 in Rambipuji, Jember, East Java, Indonesia. He is third son of Drs. Moh. Ilyas as a teacher and Fudhi Astuti as a house wife. His wife is Triwuni Purnama Wanti and his daughter is Naurah Khairunnisaa'. His older sister is Ike Yustiana and Nuhaini Faiqoh while his younger brother is Anwar Rosyid and Muhammad Ilham. He graduated from study program of mathematics education, Faculty of Teacher Training and Education, University of Jember in 2010. In 2015, he pursued his master degree of mathematics education in University of Jember. He has been a master degree student as well as teacher who is actively teaching junior high school and vocational high school in Jember. 